\title{
ENTREPRENEURIAL SPIRIT DIPENGARUHI OLEH GAYA BELAJAR AKOMODATOR PADA PEMBELAJARAN KEWIRAUSAHAAN
}

\author{
Eka Farida $^{1}$, Supriyanto ${ }^{2}$ \\ ${ }^{12}$ Fakultas Ekonomi dan Bisnis, Universitas Islam Malang \\ email: arida@unisma.ac.id
}

\begin{abstract}
The problem of educated unemployment has increased from year to year, this is due to the paradigm that the output of graduates from higher education is as a job seeker, so the application of accommodator learning styles in entrepreneurship learning is very relevant to solving these problems. The purpose of this study is to measure the accommodator learning styles of students in entrepreneurship learning and to examine the effect of accommodator learning styles on entrepreneurial learning on student entrepreneurial spirit. The research method used is experimental and ex-post facto explanatory. The population and sample in this study amounted to 35 respondents in the experimental class. Data analysis using qualitative descriptive analysis and t test. The results indicated that the learning style of the accommodator showed that the majority of students were classified as active experience, for the assessment of the student portfolio the results were very good and good. the application of the accommodator learning style was able to grow an entrepreneurial spirit by $55.3 \%$.
\end{abstract}

Keywords:Entrepreneurial Spirit, Accommodator Learning Style

Abstrak: Permasalahan pengangguran terdidik mengalami kenaikan dari tahun ke tahun, hal ini disebabkan oleh paradigma bahwa output lulusan dari perguruan tinggi adalah sebagai seorang job seeker, sehingga penerapan gaya belajar akomodator pada pembelajaran kewirausahaan sangat relevan untuk memecahkan permasalahan tersebut. Tujuan penelitian ini yaitu untuk mengukur gaya belajar akomodator mahasiswa pada pembelajaran kewirausahaan dan menguji pengaruh gaya belajar akomodator pada pembelajaran kewirausahaan terhadap entrepreneurial spirit mahasiswa. Metode penelitian yang digunakan adalah eksperimen dan ex-post facto yang bersifat eksplanasi. Populasi dan sampel dalam penelitian ini berjumlah 35 responden pada kelas eksperimen. Analisis data menggunakan analisis deskriptif kualitatif dan uji t. Hasil penelitian mengindikasikan gaya belajar akomodator menunjukkan mayoritas mahasiswa tergolong dalam active experientation, untuk penilaian portofolio mahasiswa hasilnya nilai sangat baik dan baik. penerapan gaya belajar akomodator mampu menumbuhkan entreperenurial spirit sebesar 55,3\%.

Kata kunci: Entrepreneurial Spirit, Gaya Belajar Akomodator 


\section{PENDAHULUAN}

Tingginya tingkat pengangguran serta rendahnya minat berwirausaha menjadi auto kritik terhadap peran dari perguruan tinggi sebagai penghasil output lulusan terdidik dan terlatih. Daryanto, dkk. (2012) menyatakan bahwa perguruan tinggi memiliki peran sangat besar dan memiliki peluang menumbuhkan entrepreneurial spirit sehingga lulusannya tidak hanya ahli pada suatu bidang akademik namun juga mampu melahirkan wirausahawan baru yang siap menjadi pahlawan ekonomi. Saat ini matakuliah kewirausahaan menjadi matakuliah wajib yang harus diterapkan pada semua program studi diseluruh perguruan tinggi yang ada di Indonesia. Pelatihan dan seminar kewirausahaan pun telah banyak ditawarkan oleh para praktisi dan universitas. Selain itu, berbagai literatur akademik dan artikel kewirausahaan yang muncul telah menunjukkan minat aktif terhadap studi mengenai kewirausahaan (Vesper dan Gartner, 1997; Solomon et.al., 2002; Henry et.,al.,2003). Pembelajaran kewirausahaan saat ini dijadikan sebagai salah satu mata kuliah wajib, dan sudah sesuaikah dengan kaidah dari konsep tujuan pembelajaran kewirausahaan.

Atas dasar permasalahan dan tujuan pembelajaran kewirausahaan di perguruan tinggi, maka upaya yang dianggap sesuai untuk menyelesaikan permasalahan pembelajaran tersebut adalah melalui penerapan gaya belajar akomodator pada pembelajaran kewirausahaan. Pembelajaran ini adalah sebuah gaya belajar yang inovatif, dan lebih menekankan belajar kontekstual melalui kegiatan yang komplek (Cord, 2001; Thomas, Mergendoller, \& Michaelson, 1999). Pembelajaran yang didasarkan pada gaya belajar akomodator memiliki potensi yang amat besar untuk memberi pengalaman belajar yang lebih menarik dan bermakna bagi mahasiswa (Gaer, 1998).
Hal penting dalam kajian ini adalah gagasan tentang penerapan gaya belajar akomodator pada pembelajaran kewirausahaan di program studi manajemen FEB UNISMA yang selama ini memiliki beberapa kelemahan di antaranya pada: (1) Tahap perencanaan hanya melakukan identifikasi masalah riil dan menemukan strategi pemecahan masalah; (2) Tahap pelaksanaan yang dilakukan hanya pembimbingan dalam penyelesaian tugas; dan (3) Tahap evaluasi sebatas proses aktual dari pemecahan masalah.

Dari identifikasi kelemahan tersebut, maka upaya yang dapat dilakukan untuk melakukan perbaikan yaitu dengan menerapkan gaya belajar akomodator pada pembelajaran kewirausahaan. Melalui penerapan gaya belajar akomodator, mahasiswa diarahkan untuk menggali kemampuan berwirausaha yang diukur melalui penilaian portofolio untuk menumbuhkan entrepreneurial spirit mahasiswa.

Entrepreneurial spirit memiliki peranan yang sangat besar mempersiapkan calon entrepreneur untuk memilih bekerja secara independen (Arman, dkk., 2007). Lebih lanjut Lambing \& Kuehi (2000) menyatakan bahwa seseorang inovatif, tegar meski mengalami kegagalan, confident, memiliki locus of control, mampu mengelola risiko, perubahan dipandang sebagai peluang, toleransi terhadap pilihan yang banyak, inisiatif, memiliki need for achievement, kreatif, perfection, memiliki pandangan yang luas, waktu sangat berharga, dan memiliki motivasi yang kuat adalah ciri dari seseorang yang memiliki entrepreneurial spirit. Berdasarkan uraian tersebut, entrepreneurial spirit yang difokuskan dalam penelitian meliputi: (1) kemampuan mengembangkan ide usaha; (2) kemampuan menjalin kerjasama yang baik; (3) kemampuan manajemen risiko bisnis; (4) 
kemampuan menganalisis lingkungan bisnis; (5) kemampuan menumbuhkan sifat kerja keras dan keyakinan; (6) kemampuan melakukan inovasi dan kreativitas produk; dan (7) memiliki kemampuan untuk mempengaruhi orang lain dan mampu mengelola sumber daya.

Hickoc (1995) secara umum menyatakan bahwa model gaya pembelajaran diklasifikasikan dalam tiga ruang lingkup meliputi information processing, environment, dan personality. Sedangkan Kolb (1984) mengembangkan instrumen yang digunakan untuk menilai gaya belajar seseorang melalui Learning Style Inventory (LSI). Gaya belajar yang akan digunakan dalam pembelajaran ini adalah gaya belajar akomodator. Accomodator adalah gaya belajar seseorang yang lebih menyukai pengalaman (concrete experience) dan aktif bereksperimen (active experimentation). Dengan kata lain, seseorang yang lebih menyukai mendapatkan informasi dari feeling dan memprosesnya dengan cara mempraktikkan atau melakukannya (Kolb, 1984). Gaya belajar akomodator digunakan dalam penelitian ini bertujuan untuk menilai gaya belajar mahasiswa yang mampu mengadopsi suatu produk yang sudah ada (sebatas teknik inovasi produk).

Kewirausahaan mencakup beberapa unsur penting yang saling terkait dan tidak lepas dalam kehidupan sehari-hari (Daryanto, dkk., 2012). Unsur-unsur tersebut meliputi: (1) unsur kognitif meliputi pengetahuan, daya pikir, kepandaian, dan intelektual; (2) unsur psikomotorik meliputi keterampilan dan daya inisiatif; (3) unsur afektif yang juga disebut sikap mental; dan (4) unsur intuitif (kewaspadaan). Coulter (2003), membahas proses kewirausahaan sebagai suatu proses tahapan yang menyeluruh dari dimulainya tahapan eksplorasi terhadap permasalahanpermasalahan yang memungkinkan adanya suatu harapan dan kemungkinan untuk mendapatkan kesempatan, keunggulan kompetitif yang hanya diperoleh dengan kreativitas dan inovasi untuk kemudian, serta memutuskan untuk "in action" dalam kewirausahaan. pembelajaran kewirausahaan lebih menekankan pada pemberian tugas kepada mahasiswa untuk menghasilkan suatu produk, dimana mahasiswa dilibatkan ke dalam semua aspek pembelajaran mulai menentukan, merencanakan, proses pembuatan, dan pemasaran produk. Tugas dosen sebagai fasilitator, pengawas, dan evaluator pembelajaran. Dalam pelaksanaan dilakukan pembentukan 7 kelompok kerja mahasiswa dan masing-masing kelompok kerja beranggotakan 5 orang. Setiap kelompok kerja akan menentukan, merencanakan, dan melaksanakan proyek yang dipilih, sehingga hasil akhir dari pembelajaran akan sesuai dengan harapan awal.

Hipotesis yang digunakan untuk mengukur penerapan gaya belajar akomodator pada pembelajaran kewirausahaan terhadap entrepreneurial spirit sebagai berikut.

H1. Gaya belajar akomodator pada pembelajaran kewirausahaan dapat menumbuhkan entrepreneurial spirit

Berdasarkan pengembangan hipotesis di atas aka kerangka konseptual dalam penelitian ini dijelaskan sebagai berikut.

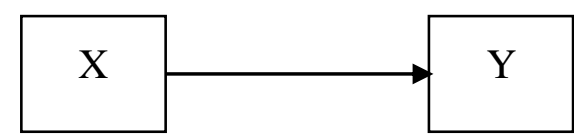

Gambar 1. Kerangka Konsep Penelitian

\section{METODE PENELITIAN}

Metode penelitian yang digunakan oleh peneliti yaitu eksperimen dan ex-post facto yang bersifat eksplanasi. Metode eksperimen digunakan untuk menguji efektifitas pembelajaran kewirausahaan 
dalam kelas eksperimen diprogram studi manajemen yang sebelumnya sudah ditentukan gaya belajar akomodator melalui learning style inventory. Sedangkan metode ex-post facto digunakan untuk menguji pengaruh pembelajaran kewirausahaan (diukur melalui nilai portofolio mahasiswa yang meliputi unsur kognitif, psikomotorik, afektif, intuitif) terhadap entrepreneurial spirit mahasiswa. Subjek uji coba sebagai partisipan atau populasi dalam penelitan ini adalah 35 mahasiswa program studi manajemen. Teknik pengambilan sampel menggunakan teknik sampling jenuh, sehingga sampel dalam penelitian ini berjumlah 35 mahasiswa.

Instrumen yang digunakan oleh peneliti dalam penelitian ini meliputi: (1) kuesioner learning style inventory yang diadopsi dari Kolb dan McCarthy (1984) untuk menerapkan gaya belajar akomodator mahasiswa; (2) kuesioner entrepreneurial spirit menggunakan pertanyaan tertutup dan cara penskoran instrumen dengan ketentuan skala likert lima skala; (3) dan portofolio digunakan untuk evaluasi pembelajaran kewirausahaan. Dan analisis data yang digunakan adalah analisis data kualitatif deskriptif dan Uji-t.

\section{HASIL DAN PEMBAHASAN}

Hasil penilaian kuesioner gaya belajar akomodator mahasiswa yang terdapat dalam kelas eksperimen menunjukkan bahwa gaya belajar mahasiswa yang menyukai pengalaman (concrete experience) sebesar $31,43 \%$ atau 11 mahasiswa dan gaya belajar mahasiswa yang aktif bereksperimen (active experimentation) sebesar $68,57 \%$ atau 24 mahasiswa. Pembelajaran kewirausahaan yang didasarkan pada gaya belajar akomodator menerapkan materi: (1) Entrepreneurial Mindset;(2) Building an Islamic Entrepreneur; (3) Create Business Idea; (4) Peluang dan Potensi Bisnis; (5) Business Plan; (6) Product, Service, \& Price; and (7) New Product Development, Services, and Brands: Building Customer Service Value. Gambaran desain produk yang dihasilkan oleh 7 kelompok kerja mahasiswa yaitu nature coffe mask, corona ice cream, bobobi, tahu walik hot, pukis buah, bokussa, dan pisang gapit. Hasil penilaian portofolio menunjukkan sebanyak 22 mahasiswa atau sebesar 62,86\% memiliki nilai belajar sangat baik (nilai rata-rata portofolio 81-100), dan 13 mahasiswa atau $37,14 \%$ memiliki nilai belajar baik (nilai rata-rata portofolio 7180). Gambar desain produk yang dihasilkan oleh mahasiswa adalah sebagai berikut.

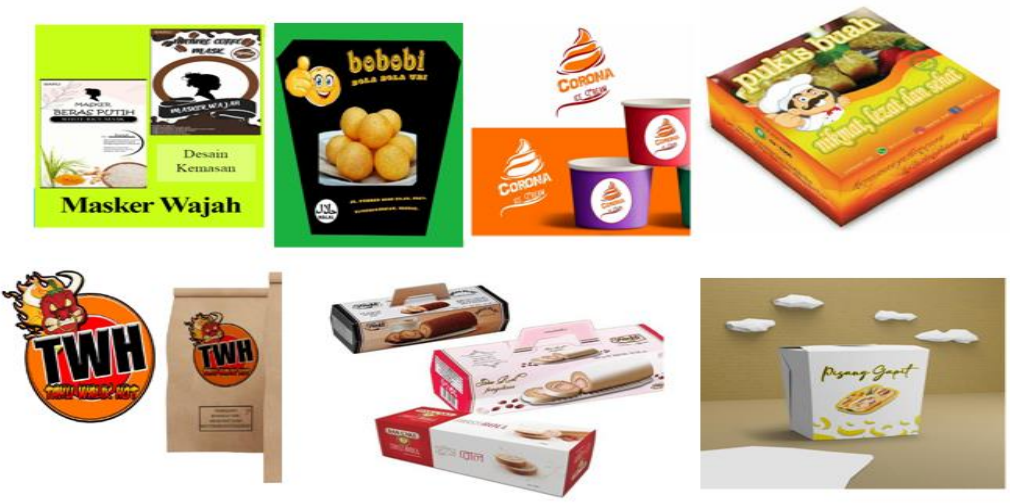

Gambar 2. Hasil Desain Kemasan Produk 
Penilaian entrepreneurial spirit didasarkan pada hasil penilaian kuesioner pada kelas eksperimen dengan hasil sebagai berikut.

1. Kemampuan mengembangkan ide usaha menunjukkan sebanyak $80 \%$ mahasiswa mampu memanfaatkan potensi di lingkungan sekitar dan selalu berusaha mencapai hasil yang lebih baik dari sebelumnya.

2. Kemampuan menjalin kerjasama menunjukkan bahwa sebesar $82,86 \%$ mahasiswa memiliki kemampuan berkomunikasi dan berinteraksi dengan semua kalangan serta selalu berusaha menyeuaikan diri dalam setiap kondisi.

3. Kemampuan manajemen risiko menunjukkan sebesar $65,71 \%$ mahasiswa mampu memperhitungkan segala risiko bisnis yang muncul atas tindakan yang dilakukan dan memiliki kesiapan untuk menghadapi setiap risiko bisnis dengan sikap optimis.

4. Kemampuan menganalisis lingkungan bisnis menunjukkan sebesar $65,71 \%$ mahasiswa mampu memperhitungkan analisis bisnis secara internal maupun eksternal serta mampu menerapkan strategi usaha yang didasarkan pada hasil analisis tersebut.

5. Kemampuan menumbuhkan sifat kerja keras dan keyakinan diri menunjukkan bahwa secara mayoritas atau sebesar $62,86 \%$ mahasiswa tergolong tipe pekerja keras yang memiliki kepercayaan pada kemampuan diri sendiri untuk memperoleh kesuksesan dalam berusaha.

6. Kemampuan melakukan inovasi dan kreativitas produk menunjukkan sebesar $57,14 \%$ mahasiswa memiliki kemampuan memanfaatkan dan menggunakan ide baru untuk meningkat usahanya dan menghasilkan produk yang sesuai dengan keinginan konsumen.

7. Kemampuan mempengaruhi orang lain dan mampu mengelola sumber daya menunjukkan sebesar $71,43 \%$ mahasiswa mampu mempengaruhi orang lain agar melaksanakan tugasnya untuk mencapai tujuan yang telah ditentukan serta mampu mengelola sumber daya secara efektif dan efisien.

Uji-t digunakan untuk mengetahui keefektifan penerapan gaya belajar akomodator pada pembelajaran kewirausahaan untuk menumbuhkan entrepreneurial spirit. Hasil dari analisis yang dilakukan memberikan hasil yang disajikan pada Tabel 1 berikut.

Tabel 1. Hasil Analisis Regresi Sederhana Gaya Belajar Akomodator pada Pembelajaran Kewirausahaan Untuk Menumbuhkan Entrepreneurial Spirit

Coefficients $^{\mathrm{a}}$

\begin{tabular}{|c|c|c|c|c|c|c|}
\hline \multirow{2}{*}{\multicolumn{2}{|c|}{ Model }} & \multicolumn{2}{|c|}{$\begin{array}{l}\text { Unstandardized } \\
\text { Coefficients }\end{array}$} & $\begin{array}{l}\text { Standardized } \\
\text { Coefficients }\end{array}$ & \multirow[b]{2}{*}{$\mathrm{t}$} & \multirow[b]{2}{*}{ Sig. } \\
\hline & & B & Std. Error & Beta & & \\
\hline 1 & (Constant) & 28.015 & 8.532 & & 3.283 & .002 \\
\hline & $\begin{array}{l}\text { Gaya Belajar Akomodator pada } \\
\text { Pembelajaran Kewirausahaan }\end{array}$ & .968 & .151 & .744 & 6.396 & .000 \\
\hline $\begin{array}{l}\mathrm{R} \\
\mathrm{R}^{2}\end{array}$ & $\begin{array}{l}: 0,744 \\
: 0,553\end{array}$ & & & $\begin{array}{l}\mathrm{F} \mathrm{h} \\
\mathrm{Sig}\end{array}$ & $\begin{array}{l}: 40 \\
: 0,\end{array}$ & \\
\hline
\end{tabular}

Sumber: Data diolah 2021 


\begin{abstract}
Variabel X (gaya belajar akomodator pada pembelajaran kewirausahaan) mempunyai angka signifikansi sebesar 0,000 yang berarti lebih kecil dari nilai probabilitas $5 \%(\mathrm{p}=0,05)$, artinya variabel $\mathrm{X}$ (gaya belajar akomodator pada pembelajaran kewirausahaan) berpengaruh signifikan terhadap variabel $\mathrm{Y}$ (entrepreneurial spirit). Analisis model summary angka $\mathrm{R}$ sebesar 0,744 menunjukkan bahwa korelasi atau hubungan antara gaya belajar akomodator pada pembelajaran kewirausahaan terhadap entrepreneurial spirit adalah kuat. Definisi "kuat" karena angka di atas 0,5. Angka R2 atau koefisien determinasi adalah 0,553 (berasal dari $0,744 \times 0,744)$. Hal ini berarti $55,3 \%$ dari entrepreneurial spirit dijelaskan oleh variabel gaya belajar akomodator pada pembelajaran kewirausahaan sedangkan sisanya sebesar $44,7 \%$ dijelaskan oleh variabel lain di luar model penelitian ini.
\end{abstract}

Penerapan gaya belajar akomodator pada pembelajaran kewirausahaan (Kolb, 1984) menunjukkan bahwa kemampuan mahasiswa menentukan, merencanakan, dan melaksanakan pembelajaran kewirausahaan dengan gaya belajar akomodator dapat menghasilkan produk yang sesuai dengan tujuan pembelajaran kewirausahaan yaitu melakukan inovasi dan kreatifitas produk. Hasil pembelajaran ini didukung dari hasil penelitian Wardoyo (2012) yang menyatakan bahwa peningkatan strategi dan metode pembelajaran yang tepat akan berdampak pada peningkatan intensitas wirausaha mahasiswa.
Aktifitas pembelajaran kewirausahaan yang dilakukan dengan menerapkan gaya belajar akomodator untuk menumbuhkan entrepreneurial spirit mahasiwa pada program studi manajemen dikonstruk dari beberapa sumber teori entrepreneurial spirit yang dijabarkan oleh Steinhoff \& Burgers (dalam Suryana, 2003) dan Arman dkk (2007). Tujuh indikator yang dipergunakan untuk mengukur entrepreneurial spirit meliputi (1) kemampuan mengembangkan ide usaha, (2) kemampuan menjalin kerjasama yang baik, (3) kemampuan manajemen risiko bisnis, (4) kemampuan menganalisis lingkungan bisnis, (5) kemampuan menumbuhkan sifat kerja keras dan keyakinan diri, (6) kemampuan melakukan inovasi dan kreativitas produk, dan (7) memiliki kemampuan mempengaruhi orang lain dan mengelola sumber daya.

Hasil analisis kuesioner mengindikasikan bahwa mahasiswa yang sudah mengikuti pembelajaran kewirausahaan dengan gaya belajar akomodator memiliki entrepreneurial spirit yang sangat baik. Hal ini ditunjukkan dari kemampuan yang sangat baik pada kemampuan mengembangkan ide usaha, kemampuan menjalin kerjasama, manajemen risiko bisnis, menganalisis lingkungan bisnis, dan mampuan mempengaruhi orang lain dan mengelola sumber daya, serta kemampuan yang baik terkait dengan menumbuhkan sifat kerja keras, keyakinan diri, melakukan inovasi dan kreativitas produk. 
Hasil ini sejalan dengan penelitian yang telah dilakukan oleh Aghajani \& Abbasgholipour (2012) yang menunjukkan bahwa program pembelajaran kewirausahaan di perguruan tinggi sangat berkontribusi untuk menumbuhkan entrepreneurial spirit mahasiswa meliputi kreativitas, inovasi, manajemen risiko, pengendalian secara internal dan eksternal, kemandirian, motivasi untuk berkembang, dan optimisme yang tinggi dalam berwirausaha. Selain itu kontribusi besar yang dapat digunakan untuk membangun entrepreneurial spirit di Indonesia yaitu pengetahuan, evaluasi, dan jenis kelamin (Susilo, 2014). Dari hasil paparan tersebut, dapat disimpulkan bahwa penerapan gaya belajar akomodator pada pembelajaran kewirausahaan mampu menumbuhkan entrepreneurial spirit mahasiswa pada program studi Manajemen FEB Unisma.

\section{SIMPULAN}

Berdasarkan hasil penelitian dan pembahasan, maka kesimpulan dari penelitian yang telah dilakukan adalah sebagai berikut.

1. Kelas uji model adalah kelas eksperimen penerapan gaya belajar akomodator berdasarkan concrete experience (menyukai pengalaman) dan active experimentation (aktif bereksperimen), dimana hasil penilaian menunjukkan mayoritas mahasiswa tergolong dalam active experientation.

2. Penilaian portofolio didasarkan pada nilai rata-rata dari penerapan gaya belajar akomodator pada pembelajaran kewirausahaan, dengan hasil nilai sangat baik dan baik.

3. Entrepreneurial spirit menunjukkan hasil bahwa mahasiswa yang menempuh pembelajaran kewirausahaan dengan gaya belajar akomodator memiliki entrepreneurial spirit yang sangat baik.
4. Uji keefektifan penerapan pembelajaran gaya belajar akomodator pada pembelajaran kewirausahaan, pembagian kelompok kerja, penilaian portofolio, dan desain produk yang dihasilkan mampu menumbuhkan entrepreneurial spirit mahasiswa dengan sangat baik.

\section{DAFTAR RUJUKAN}

Arman, H. dkk. (2007). Entrepreneurship Membangun Spirit Teknopreneurship. Yogyakarta: Andi.

Cord. (2001). Contextual Learning Resource. Tersediapada:http://www.cord.org/lev2.cf $\underline{\mathrm{m} / 65}$. Diakses tanggal: 2 Maret 2001.

Coulter, M. (2003). Entrepreneurship in Action. New Yersey: Prentice Hall.

Daryanto, dkk. (2012). Pengantar Kewirausahaan. Bogor: IPB. Tidak Dipublikasikan.

Gaer. (1998). Whats is Project-Based Learning? http://members.aol.com, diakses pada tanggal 7 September 2013.

Henry, C., Hill, F., \& Leitch, C. (2003). Entrepreneurship Education and Training. Ashgate Aldershot.

Hickocx, L.K. (1995). Learning Style: A Survey of Adult Learning style Inventory Model. In R.R. Sims \& S.J. Sims (Eds). The Importance of learning Style: Understanding The Implication for Learning, Course design, and Education. Wesport, CT: Grenworod Press.

Kolb, D.A. (1984). Learning style Inventory Self Scoring Inventory and Interpretation Buuklt. Boston, NA: MCBER and Company.

Kolb, D.A. \& McCharty. (1984). GNVQ 7 Learning Style Inventory (adapted Kolb 
and McCharty). http://search?q=kolb+mccharty\&btnG=\&c lient., diakses pada 12 Januari 2013.

Lambing, P.A. \& Kuehl, C.R. (2002). Entrepreneurship. Second Edition. New Jersey: Prentice Hall.Boston, NA: MCBER and Company.

Lawrence, et.al. (2005). Health Education Planing A Diagnostik Approach, The Johns Hapkins University. Mayfield Publishing Company.

Moursund, D.G. (1997). The Feture of Information Technology in Education. http://darkwing.uoregon.edu/moursund/books/futuresbook1997/index.h tml. Diakses pada tanggal 1 januari 2013.

Solomon, G.T., Duffy, S. \& Tarabishy, A. (2002). The State of Entrepreneurship Education in The United States: A Nationwide Survey and Analysis. International Journal of Entrepreneurship Education, Vol. 1 No. 1, pp. 1-22.

Suryana. (2003). Kewirausahaan: Pedoman Praktis, Kiat, dan Proses Menuju Sukses. Jakarta: Prehalindo.
Susilo, W.H. (2014). An Entrepreneurial Mindset and factors Effect on Entrepreneurs Spirit in Indonesian. The SIJ Transactions on Industrial, Financial \& Business Management (IFBM), Vol. 2, No. 4, June 2014.

Thomas, J.W. (2000). A Review of Research on Project Based Learning. http://www.autodesk.com/, diakses pada tanggal 18 July 2013.

Thomas, JW, Mergendoller, JR \& Michaelson, A. (1999). Project Base Learning: A handbook of Midle and High School Teacher. Novato CA: The Buck Institute for Education.

Vesper, K.H. \& Gartner, W.B. (1997). Measuring Progress in Entrepreneurship Education. This papaer presented at the National Academy of Management Association Meeting. Cincinati, Ohio, 914 August.

Wardoyo. (2012). Pengaruh Pendidikan dan Karakteristik Kewirausahaan Terhadap Intensi Berwirausaha Mahasiswa Pada Perguruan Tinggi Swasta di Jakarta. Seminar NasionalKewirausahaan dan Inovasi Bisnis II. Jakarta: Universitas Tarumanegara, 18 September 2012. 